\title{
Fecundity and Gonadosomatic Index of Sucker Throat Catfish, Pseudecheneis sulcata (McClelland, 1842) from the Snow-fed Tamor River in Eastern Nepal
}

\author{
DIPAK RAJBANSHI ${ }^{1}$, JASH HANG LIMBU $^{* 2,3}$, PRAKASH KUMAR $^{1} \&$ BHARAT RAJ \\ SUBBA $^{1}$
}

\begin{abstract}
${ }^{1}$ Post Graduate Campus, Department of Zoology, Tribhuvan University, Biratnagar, Nepal; ${ }^{2}$ Nature Conservation and Health Care Council, Biratnagar (NCHCC), Nepal; ${ }^{3}$ Central Campus of Technology, Department of Zoology, Hattisar, Dharan, Nepal

Corresponding author: limbujash@gmail.com/jash.limbu@ natureconservation.org.np

Received: 19 July $2021 \quad$ Accepted: 1 December $2021 \quad$ Published: 31 December 2021
\end{abstract}

\begin{abstract}
In comparison to other nations, the Nepalese information on the reproductive biology of hill-stream fish is limited. So, the purpose of the present study was to provide information related to reproductive biology of a hill-stream sucker throat catfish Pseudecheneis sulcata from the snow-fed Tamor River, Nepal. The study was carried out from June 2018 to May 2019. A total of 57 female fish was collected. The fecundity of 22 females was assessed, while the gonadosomatic index was determined using all the collected samples. The absolute fecundity ranged from 2,316 to 7,597 eggs, with an average of 3,660 \pm 210 . This range of absolute fecundity indicates that Pseudecheneis sulcata is a moderately fecund fish when compared to certain low fecund species and some exceptionally fecund fish with tens of thousands of eggs. Relative fecundity ranged from 65.47 to 129.11 with a mean of $88.98 \pm 4.35$. The present study demonstrated that absolute fecundity was moderately correlated with total length $(r=0.45)$ and strongly linked with body weight $(r=0.78)$, and ovary weight $(r=0.80)$. Mean gonadosomatic index (GSI) was recorded the highest in January $(15.7 \pm 1.22 \%)$, and showed a decrease in the subsequent month of February $(10.3 \pm 0.75 \%)$, March $(6.25 \pm$ $0.28 \%)$ and April $(1.66 \pm 0.40 \%)$. The trends of GSI might have indicated that the sucker throat catfish was a batch spawner, with spawning season occuring between January and March.
\end{abstract}

Keywords: Catfish, glacier fed, hill stream, reproductive biology

Copyright: This is an open access article distributed under the terms of the CC-BY-NC-SA (Creative Commons Attribution-NonCommercial-ShareAlike 4.0 International License) which permits unrestricted use, distribution, and reproduction in any medium, for non-commercial purposes, provided the original work of the author(s) is properly cited.

\section{INTRODUCTION}

Pseudecheneis sulcata is a unique fish, commonly known as sucker throat catfish. It inhabits fast flowing hill-streams, with the bottom of sand, gravel, rocks and is native to fresh water bodies of Southern Asia, i.e. Bangladesh and India (Ng, 2010). It also inhabits the fresh water bodies like Gandaki, Seti and Koshi Rivers of Nepal (Shrestha, 2019). Sucker-like mouth encircled by many fimbriated barbs and a ventrally situated adhesive pad with 10-12 transverse ridges are among the adaptive modifications. The fish is a bottom dweller which mainly feeds upon other bottom dweller crustaceans, algae attached to rocks, some aquatic insects, larvae etc. Fecundity is the ability to produce an abundance of offsprings. Fecundity, gonadosomatic index (GSI), and lengths at sexual maturity are crucial biological characteristics for understanding the reproductive dynamics of certain fish species, as these characteristics reveal their maturity and spawning activity (Murua et al., 2003; Rasheed \& Mustaquim, 2010). In context of fish biology, it is defined as the number of mature ova present in the ovary of gravid female fish and relative fecundity is the number of ova per gram of fish weight. Instead of measuring reproductive fertility, fecundity is studied as a point of reproductive measurement (Moyle \& Cech, 2000).

Fecundity is defined as an individual's physiological maximum potential reproductive production across their lifetime, and it is a crucial cornerstone of both theoretical and applied population biology (Bradshaw \& McMahon, 2008). Moreover, Flores et al. (2015) stated that gonadosomatic index is a metric that represents the relative weight of the gonad to the fish weight. The peak period of maturity and the spawning 
season can be detected by the study of GSI of fish.

Human activities, fishing pressure, climate change, ongoing road building, micro-hydropower generation, the use of herbicides, electro-fishing, deforestation, and water diversion have all contributed to the decline of several Nepalese fisheries populations (Adhikari et al., 2021; Limbu et al., 2021a). Moreover, mostly in the hill side of Nepal, ongoing road evelopment is found to be major threat to the present fish species such as Pseudecheneis spp., Garra spp., Schizothorax spp., Shistura spp. and Nemachelius spp. (Limbu et al., 2021b; Prasad et al., 2020).

There is no such sufficient information about the biology and population dynamic of $P$. sulcata, though it is believed that the fish is abundantly found in the fresh water of Southern Asia and regarded as least concern in the Red list of IUCN (Ng, 2010). The published literature on the reproductive aspect on this species is very scanty. Thus, the present study of fecundity attempted to enhance the knowledge of the reproductive biology of $P$. sulcata as well as provide the necessary information for its conservational strategy.

\section{MATERIALS AND METHODS}

\section{Study Area}

Tamor River lies in the eastern Nepal, which begins around Kanchenjunga (Figure 1). It is one of the seven major tributaries of Giant Saptakoshi River of Nepal. It lies between the latitude and

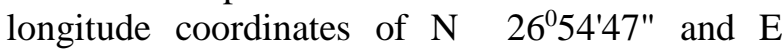
$87^{\circ} 09^{\prime} 30^{\prime \prime}$, respectively. The river and its main tributaries originate from Mount Kanchenjunga which is the third highest peak in the world and flows towards eastern part of country. The Tamor and Arun join the Sunkoshi at Tribenighat to form the Giant Saptakoshi River which flows through Mahabharat range. The total length of the river is approximately $190 \mathrm{~km}$ with catchment area of $5817 \mathrm{~km}^{2}$ (Shrestha et al., 2009). Boulders, cobbles, pebbles, gravels and sand were the major characteristic feature of the bottom of this river.

\section{Data Collection}

\section{Sample collection}

Sampling was conducted once a month for a year at four different sampling sites. The female fish were collected from their natural habitat from June 2018 to May 2019 by using two cast nets of different sizes, with one having large mesh size with $2 \mathrm{~cm}, 6 \mathrm{~m}$ diameter and $6 \mathrm{~kg}$ weight and another having $0.5 \mathrm{~cm}, 3 \mathrm{~m}$ diameter and $2 \mathrm{~kg}$ weight. However, sampling was restricted in some areas due to difficulties of access. In addition, monofilament gill nets with mesh sizes of 6,8 , and $10 \mathrm{~mm}$ were used to capture the fish. In each station, nine gill nets were left late in the evening (5 p.m. - 6 p.m.) and taken out early in the morning (6 a.m. - 7 a.m.) in a sampling distance of 150 - 200 m (Limbu et al., 2021a). Samples were preserved in 8-10\% formaldehyde solution and brought to the laboratory of Post Graduate Campus, Biratnagar for further investigation.

\section{Measurement of length and weight}

A total of 57 specimens of female $P$. sulcata was sampled during the study period. Each specimen's total length (TL) and body weight (BW) were

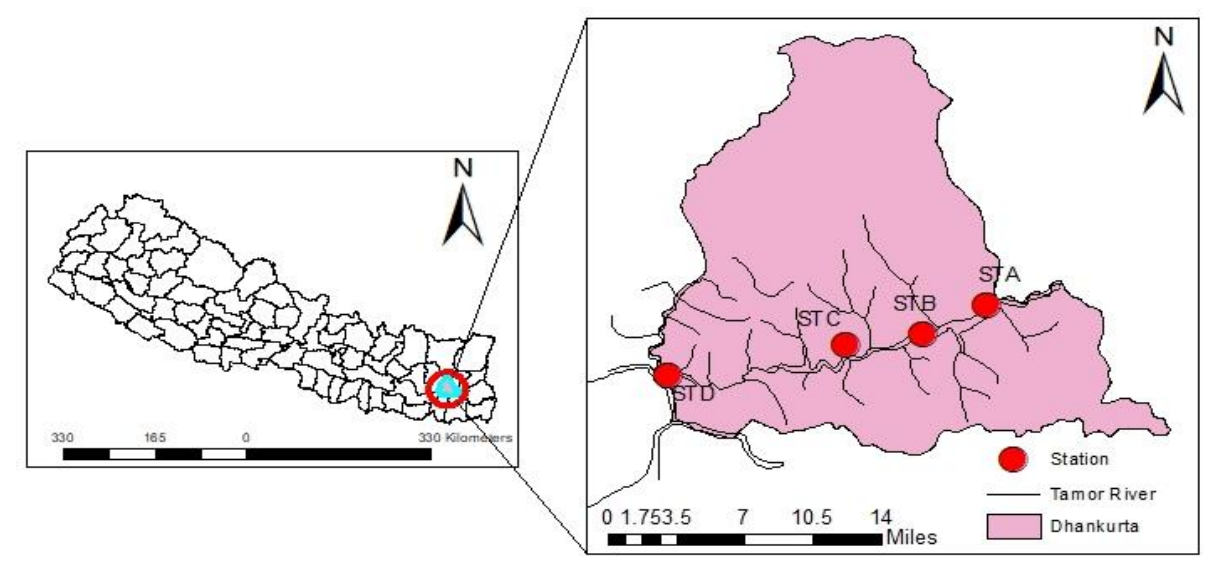

Figure 1. Map of study area showing Tamor River 
measured to the nearest the nearest $0.01 \mathrm{~cm}$ and $0.01 \mathrm{~g}$ using a measuring scale and a digital electronic weighing balance, respectively. Fish were dissected to expose ovaries. The ovary of each fish was carefully taken out and weighed in weighing balance after soaking water with blotting paper.

\section{Gonadosomatic index (GSI)}

The gonadosomatic index of each specimen was calculated and recorded with respect to the months. Mathematically, GSI of each fish was calculated by using the following formula.

GSI $=\frac{\text { ovary weight }}{\text { total weight of fish }} \times 100$

\section{Fecundity estimation}

A total of 22 mature female fish was used for fecundity estimation. Fecundity was estimated using a gravimetric method (Hunter \& Goldberg, 1980; Hunter et al., 1992; Murua et al., 2003). The ovary of the catfish is bi-lobed. Ovary was cut off into three parts (samples) i.e. anterior, middle and posterior. Then from each sample, 50 $\mathrm{mg}$ of sub-samples were taken and kept in Gilson's fluid for 5 - 7 days. The Gilson's fluid was prepared in the laboratory. The Gilson's fluid loosens the connective tissues and makes easy for separating the eggs. The separated eggs were counted using the hand lens (5X) and pointed needle. The total number of eggs in each ovary samples were estimated using the equation as follows.

$f 1=\frac{\text { Ovary weight } \times \text { Number of oocytes in the subsample }}{\text { weight of subsample taken }}$

Subsequently, the total absolute fecundity (F) for each female fish was estimated by taking the mean of all three sample fecundities i.e. $f_{1}, f_{2}, f_{3}$, Furthermore, relative fecundity was estimated by dividing individual absolute fecundity with the weight of respective fish.

\section{Data Analysis}

The analysis of variance (ANOVA) was used to assess significant variations in the GSI index across samples taken on different months. A post hoc Tukey HSD test was employed to identify which means were significantly different at a 0.05 significance level (Spjøtvoll \& Sttoline, 1973). Pearson's correlation coefficient (r) and regression equations were used to determine the strength and significance of the connections between absolute fecundity, total length and weight, and gonad weight. All the data were analyzed in $\mathrm{R}$ ( $\mathrm{R}$ core team, 2019) and Microsoft Excel 2010 software.

\section{RESULTS}

The absolute fecundity ranged from 2,316 to 7,597 eggs in fish of TL range of $13.6 \mathrm{~cm}$ to 18.3 $\mathrm{cm}$, body weight range of $21.81 \mathrm{~g}$ to $68.25 \mathrm{~g}$ and ovary weight range of $1.17 \mathrm{~g}$ to $11.87 \mathrm{~g}$ (Table 1 ). The highest fecundity was found to be 7597 eggs in the fish measuring $18.3 \mathrm{~cm}$ TL, $68.25 \mathrm{~g} \mathrm{BW}$ and $11.87 \mathrm{~g}$ OW while the fecundity was counted 2316 in the specimen measuring $15.7 \mathrm{~cm} \mathrm{TL}$, $23.89 \mathrm{~g} \mathrm{TW}$ and $1.17 \mathrm{~g} \mathrm{OW}$. Mean fecundity of fish was found to be $3660 \pm 210$ at the mean length of $16.14 \pm 0.31 \mathrm{~cm}, 43.29 \pm 2.87 \mathrm{~g}$ in mean total weight and $5.24 \pm 0.63 \mathrm{~g}$ mean ovary weight of fish (Table 1).

The relative fecundity to weight ranged from 65.47 in the fish measuring total weight 59.64 to $129.11 \mathrm{~g}$ in the fish measuring total weight 21.81 g. Mean relative fecundity was found to be 88.98 \pm 4.35 . The highest value of mean GSI was seen during the month of January $(15.70 \pm 1.22 \%)$, which decreased to $10.30 \pm 0.75 \%$ in the month of February and also showed continuous decreasing trend during the month of March and April to $6.25 \pm 0.28 \%$ and $1.66 \pm 0.40 \%$, respectively. This ongoing decrease in the GSI suggested that fraction of eggs were spawned during several months. The variation of monthly GSI values for female fish showed that fish spawned during the month of late January to late March (Figure 2, Table 2). An analysis of variance (ANOVA) pointed that there is a significant $(p<0.001)$ difference between the GSI in 12 months but Tukey HSD test indicated that there was no significant $(p=0.09)$ difference between the months of November and December.

Fecundity of fish varied from 2,316 to 7,597 in the fish measuring 15.7 to $18.3 \mathrm{~cm}$ in TL (Table 1). Straight line was obtained while plotting the values of fecundity and TL with the coordinates $\mathrm{Y}$-axis and $\mathrm{X}$-axis respectively (Figure 3). Regression equation was obtained as follows.

$y=302.11 x-1216.9$ 
Table 1. Total length, body weight, ovary weight and absolute fecundity of sampled female Pseudecheneis sulcatus from Tamor River, Nepal

\begin{tabular}{cccccc}
\hline S.N & $\begin{array}{c}\text { Body Weight } \\
\mathrm{W}(\mathrm{g})\end{array}$ & $\begin{array}{c}\text { Total length } \\
\text { TL }(\mathrm{cm})\end{array}$ & $\begin{array}{c}\text { Ovary Weight } \\
\text { OW }(\mathrm{g})\end{array}$ & $\begin{array}{c}\text { Absolute fecundity } \\
(\mathrm{F})\end{array}$ & $\begin{array}{c}\text { Relative fecundity } \\
\text { to total weight }(\mathrm{RF})\end{array}$ \\
\hline 1 & 55.43 & 16.7 & 7.9 & 3914 & 70.61 \\
2 & 68.25 & 18.3 & 11.87 & 7597 & 111.31 \\
3 & 47.68 & 16.4 & 5.22 & 3515 & 73.72 \\
4 & 33.46 & 14.1 & 6.26 & 3654 & 109.20 \\
5 & 50.75 & 14.8 & 10.24 & 4018 & 79.17 \\
6 & 52.89 & 17.5 & 6.96 & 3715 & 70.24 \\
7 & 45.75 & 17.1 & 7.01 & 3872 & 84.63 \\
8 & 59.64 & 18.1 & 5.02 & 3905 & 69.47 \\
9 & 50.39 & 17.7 & 5.18 & 3496 & 69.40 \\
10 & 52.17 & 15.3 & 4.96 & 3621 & 75.14 \\
11 & 48.89 & 15.1 & 6.36 & 3674 & 68.81 \\
12 & 50.67 & 16.9 & 5.25 & 3487 & 110.57 \\
13 & 28.17 & 15 & 1.75 & 3115 & 129.11 \\
14 & 21.81 & 13.6 & 1.60 & 2816 & 96.94 \\
15 & 23.89 & 15.7 & 1.17 & 2316 & 105.44 \\
16 & 30.1 & 15.2 & 1.79 & 3174 & 110.28 \\
17 & 25.37 & 14.7 & 1.59 & 2798 & 116.49 \\
18 & 25.88 & 17.5 & 1.7 & 3015 & 115.62 \\
19 & 27.65 & 14.2 & 1.83 & 3197 & 74.30 \\
20 & 53.17 & 18.1 & 7.59 & 3951 & 75.74 \\
21 & 48.61 & 17.8 & 6.8 & 3682 & 76.10 \\
22 & 51.8 & 15.4 & 7.3 & 3942 & $88.98 \pm 4.35$ \\
\hline Mean \pm SE & $43.29 \pm 2.87$ & $16.14 \pm 0.31$ & $5.24 \pm 0.63$ & $3660.77 \pm 210.74$ & \\
\hline
\end{tabular}

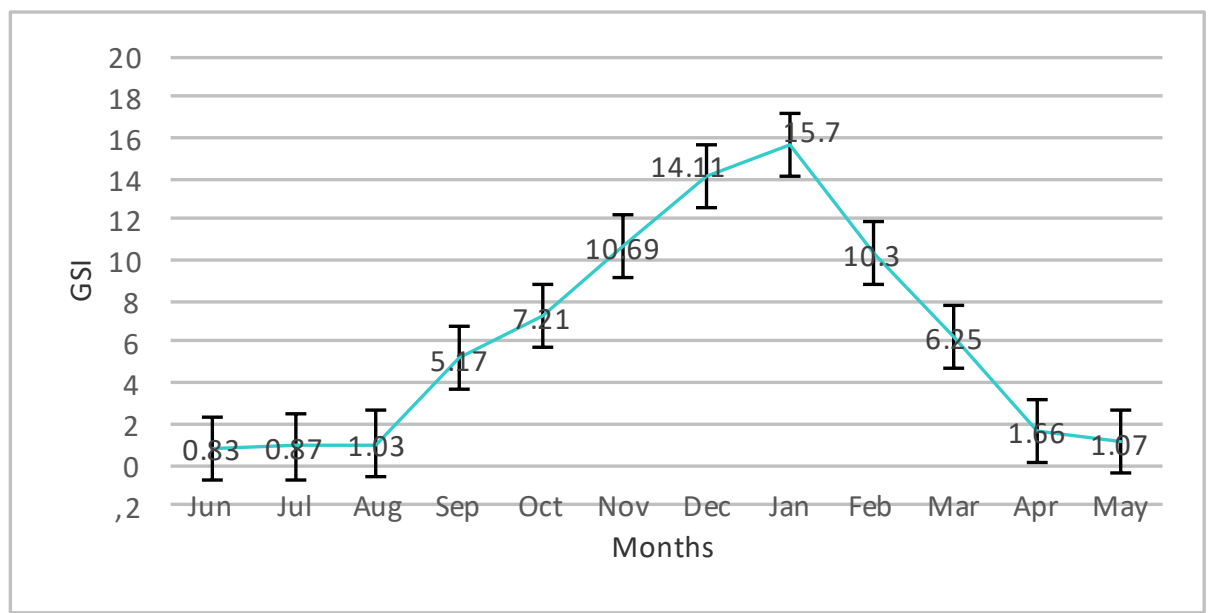

Figure 2. Mean monthly gonadosomatic index of Pseudecheneis sulcata

The correlation coefficient was $\mathrm{r}=0.452(\mathrm{p}=$ 0.0067), which implied significantly positively relationship between the ovary weight and fecundity.

Fecundity of fish varied from 2,316 to 7,597 in the fish measuring $21.81 \mathrm{~g}$ to $68.25 \mathrm{~g}$ in BW. Straight line was obtained while plotting the values of fecundity and total weight with the coordinates $\mathrm{Y}$-axis and $\mathrm{X}$-axis respectively (Figure 4). Regression equation was obtained as follows.

$y=53.373 x+1350.1$ 
Table 2. Monthly gonadosomatic index of Pseudecheneis sulcata

\begin{tabular}{cccc}
\hline Months & $\begin{array}{c}\text { No. of fish } \\
\text { examined }\end{array}$ & GSI range & Mean GSI \\
\hline June 2018 & 2 & $0.61-1.05$ & 0.83 \\
July 2018 & 4 & $0.63-1.05$ & 0.87 \\
August 2018 & 6 & $0.85-1.27$ & 1.03 \\
September 2018 & 5 & $4.79-6.08$ & 5.17 \\
October 2018 & 9 & $5.83-9.17$ & 7.21 \\
November 2018 & 4 & $9.85-11.37$ & 10.69 \\
December 2018 & 3 & $13.98-14.27$ & 14.11 \\
January 2019 & 7 & $10.94-20.17$ & 15.7 \\
February 2019 & 5 & $8.41-10.36$ & 10.3 \\
March 2019 & 7 & $4.89-7.33$ & 6.25 \\
April 2019 & 3 & $0.85-2.11$ & 1.66 \\
May 2019 & 2 & $1.05-1.09$ & 1.07 \\
\hline
\end{tabular}

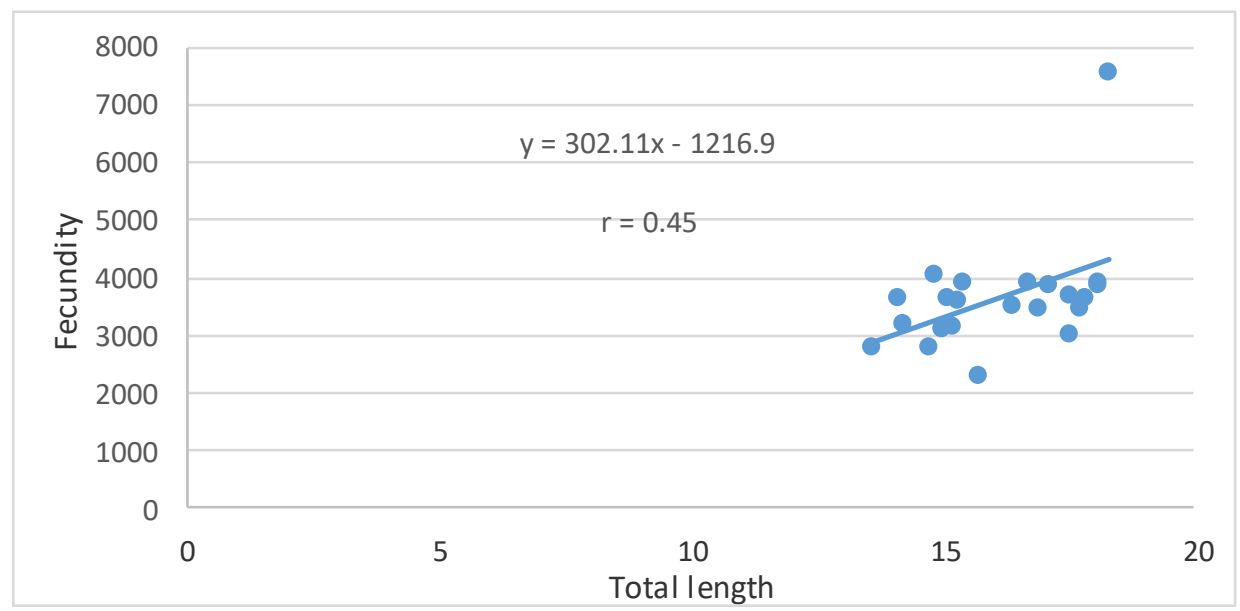

Figure 3. Relationship of fecundity with total length of Pseudecheneis sulcata

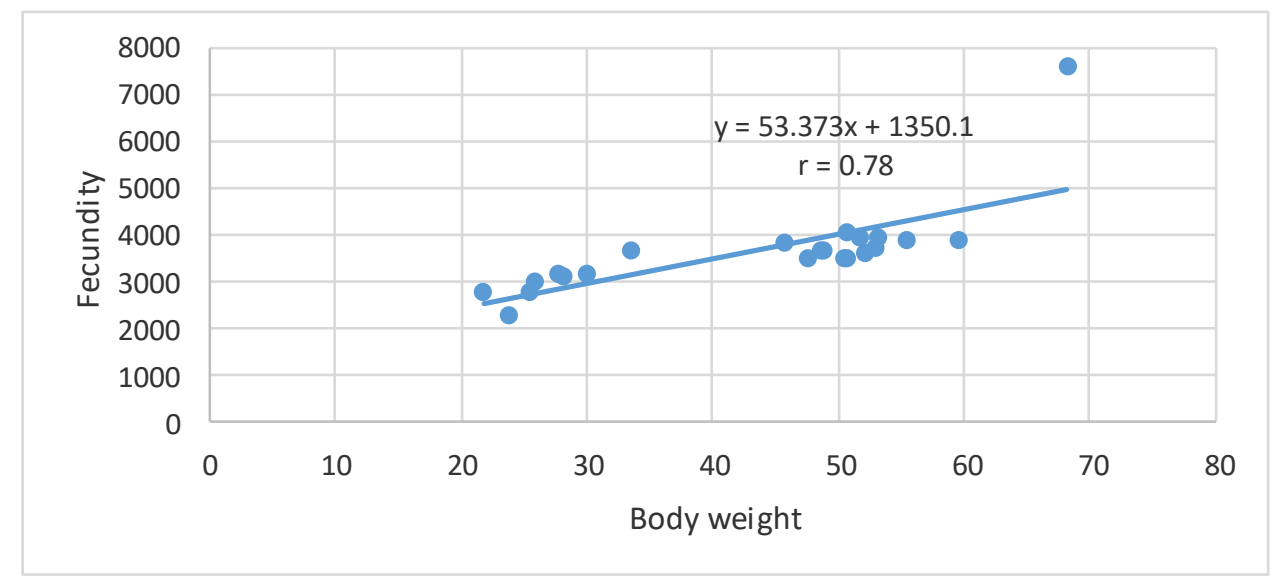

Figure 4. Relationship of fecundity with body weight of Pseudecheneis sulcata 
The correlation coefficient (r) of 0.78 was obtained $(p=0.005)$, which implied that there was positive correlation.

Fecundity of fish varied from 2,316 to 7,597 in the fish measuring $1.17 \mathrm{~g}$ to $11.87 \mathrm{~g}$ in ovary weight. Straight line was obtained while plotting the values of fecundity and ovary weight with the coordinates $\mathrm{Y}$-axis and $\mathrm{X}$-axis respectively
(Figure 5). Regression equation was obtained as follows.

$y=264.49 x+2274$

The correlation coefficient ( $\mathrm{r}$ ) of 0.8 was obtained, which implied that there was positive correlation and was highly significant $(\mathrm{p}=$ 0.0057).

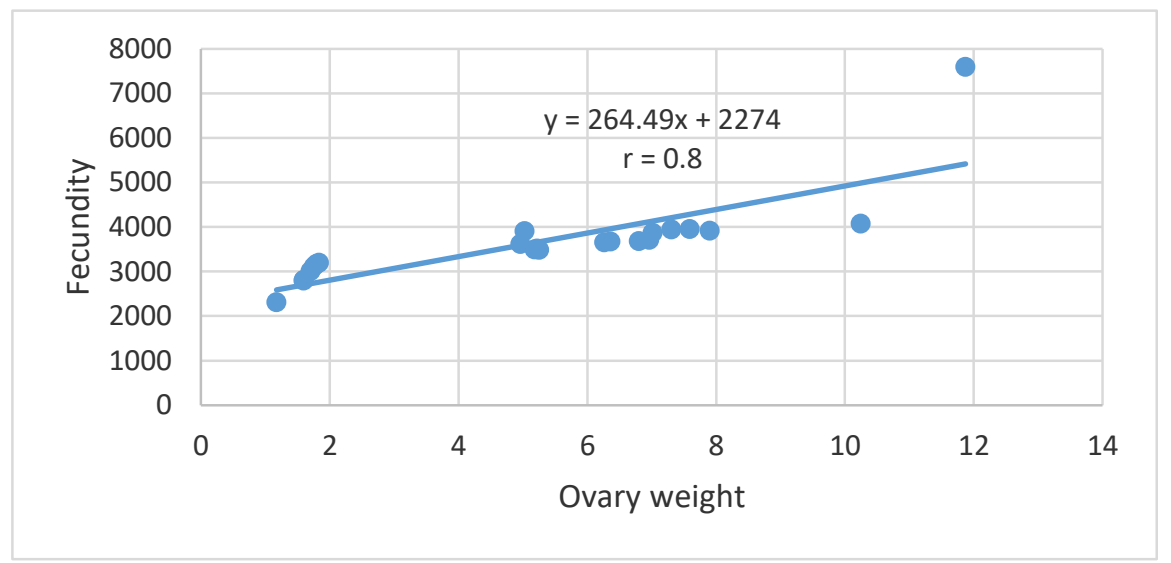

Figure 5. Relationship between fecundity and ovary weight of Pseudecheneis sulcata

\section{DISCUSSION}

Throughout the study period, total weight of the 22 female fish $P$. sulcata specimens ranged from 21.81 to $68.25 \mathrm{~g}$. It differed from each other on the different sampling months (Table 1). The fish accomplished the highest length in January and the lowest length in May. In the present study, the ovarian weight ranged from 1.17 to $11.87 \mathrm{~g}$. Generally, the ovarian weight of the fish depends on the number of oocytes and the degree of maturity of female fish (Hasan et al., 2020). The gravimetric method done in this study was also applied by many researchers (Blay, 1981; Mustafa et al., 1983; Nandikeswari et al., 2014; Hasan et al., 2020). The present study showed the fecundity of fish ranged from 2316 to 7597 . The highest fecundity was found to be 7597 in the fish measuring $18.3 \mathrm{~cm} \mathrm{TL}, 68.25 \mathrm{~g}$ TW and $11.87 \mathrm{~g}$ OW whereas, lowest fecundity was recorded as 2316 in the specimen measuring $15.7 \mathrm{~cm} \mathrm{TL}$, $23.89 \mathrm{~g} \mathrm{TW}$ and $1.17 \mathrm{~g}$ OW. This range of fecundity made $P$. sulcata a moderately fecund fish compared to some of highly fecund fishes with tens of thousands of eggs and some low fecund fishes with hundreds of eggs.

Thapliyal and Balodi (2015) studied the fecundity of $P$. sulcata in Alaknanda, Garhwal
Himalaya and reported the range of fecundity similar to present study but spawning season was found to be occurring during the month of JuneJuly whereas, in the present study $P$. sulcata showed the spawning season coinciding with the month of late January to late March. The difference in the spawning season of same species might be due to the ecological condition of streams and different in monsoon arrival time which caused the maturation of fish. The ecological condition of streams and early arrival of monsoon plays important role on maturation phases and might cause slight difference in spawning season.

The present study reported highest mean (GSI) of fish in the month of January $(15.70 \pm 1.22 \%)$, which ongoing fell to $10.30 \pm 0.75 \%, 6.25 \pm$ $0.28 \%$ and $1.66 \pm 0.40 \%$ in the month of February, March and April respectively. This implied the spawning season of fish coincides with the month of January to March.

The regression equations and scattered diagrams showed a positive but non-robust relationship of fecundity with the total length ( $r=$ $0.8)$ and total weight $(r=0.78)$ but poorly correlated with total length $(r=0.452)$. 
In contrary, a similar strong association between fecundity and body weight was discovered. As a result, it is clear that as the standard length and or body weight of $P$. sulcata grew, the fecundity or number of oocytes increased as well. This is due to the fact that larger fish have more accessible energy and a larger body cavity for the development of oocytes (Jonsson \& Jonsson, 1999). Furthermore, the findings of Kabir et al. (1998) is analogous to the current findings. The ability of fish to produce oocytes is influenced by a variety of physical and environmental parameters, including age, sex, size, species type (Hunter et al., 1992), life history, and water temperature (Mousavi-Sabet et al., 2017).

The human-induced activities like electrofishing, poisoning of river, mass fishing, detonation in the name of economics and fun had become serious threat to the population of $P$. sulcata and whole fish diversity of Tamor River. Moreover, ongoing road development, microhydropower generation, the use of poisonous herbicides, illegal electro-fishing, deforestation and water diversion are all found to be major threats to the present fish species of Nepal's rivers, stream, ponds, lakes and reservoir (Limbu et al., 2020; 2021). Therefore, for the better monitor, management and conservation of Nepal's indigenous fish species, habitat rehabilitation, and construction of fish ladders/passage are necessarily needed. Moreover, extraction and transportation of boulders, cobbles, pebbles and sand mining are also stringently stopped in ordered to avoid the habitat destruction of aquatic fauna and flora including fish.

\section{CONCLUSION}

The fertility of 22 females was evaluated, and the gonadosomatic index was calculated using all of the samples gathered. The absolute fecundity ranged from 2316 to 7597 eggs with an average of $3660 \pm 210$. When compared to some low-fecund species and some very fecund fish with tens of thousands of eggs, this range of absolute fecundity indicates that Pseudecheneis sulcata is a fairly fecund fish. Relative fecundity ranged from 65.47 to 129.11 with a mean of $88.98 \pm 4.35$. The highest mean gonadosomatic index (GSI) was reported in January $(15.7 \pm 1.22 \%)$, followed by decreases in February (10.3 $\pm 0.75 \%)$, March $(6.25 \pm 0.28 \%)$ and April $(1.66 \pm 0.40 \%)$. The sucker throat catfish's GSI pattern may have indicated that it was a batch spawner, with spawning season falling between January and March. This period of months might need to be incorporated in managing fisheries resources in the Tamor River.

\section{ACKNOWLEDGEMENTS}

The authors are grateful to Mr. Yam Bahadur Mahato and Mr. Roshan Rajbanshi for their help in laboratory work. We are highly indebted to Mr. Gyan Bahadur Shrestha and Ms. Kesika Shrestha for fish collection, lodging and fooding facilities.

\section{REFERENCES}

Adhikari, A., Limbu, J.H. \& Pathak, S. (2021). Fish diversity and water quality parameters of Mechi River, Jhapa, Province No. 1, Nepal. Borneo Journal of Resource Science and Technology, 11(1): 24-34. DOI: https://doi.org/ $10.33736 /$ bjrst.2954.2021

Blay, J.J. (1981). Fecundity and spawning frequency of Sarotherodon galilaeus in a concrete pond. Aquaculture, 25(1): 95-99.

Bradshaw, C.J.A. \& McMahon, C. R. (2008). Fecundity. In Encyclopedia of Ecology. Science direct.com/topics/agricultural and biological science/fecundity.

Flores, A., Wiff, R. \& Diaz, E. (2015). Using the gonadosomatic index to estimate the maturity ogive: application to Chilean hake (Merluccius gayi gayi). ICES Journal of Marine Science, 72(2): 508-514. DOI: https://doi.org/10.1093/ icesjms/fsu155

Hasan, M., Hosen, M.H.A. Miah, M.I., Ahmed, Z.F., Chhanda, M.S. \& Shahriar, S.I.M. (2020). Fecundity, length at maturity and gonadal development indices of river catfish (Clupisoma garua) of the old Brahmaputra River in Bangladesh. Egyptian Journal of Aquatic Research, 46(3): 259-263. DOI: https://doi.org/10.1016/j.ejar.2020.08.003

Hunter, J.R. \& Goldberg, S.R. (1980). Spawning incidence and batch fecundity in northern anchovy, Engraulis mordax. Fishery Bulletin, 77(3): 641-652.

Hunter, J.R., Macewicz, N. \& Kimbrell, C.A. (1992). Fecundity, spawning and maturity of 
female Dover sole, Microstomus pacificus with an evaluation of assumptions and precision. Fishery Bulletin, 90: 101-128.

Jonsson, N. \& Jonsson, B. (1999). Trade-off between egg mass and egg number in brown trout. Journal of Fish Biology, 55(4): 767-783. DOI: https://doi.org/ 10.1111/j.10958649.1999.tb00716.x

Kabir, A.K., Hossain, M.A., Rahmatullah, S.M., Dewan, S. \& Islam, M.S. (1998). Studies on the gonadosomatic index and fecundity of chapila (Gudusia chapra Hamilton). Bangladesh Journal of Fishery Research, 2(2): 195-200.

Limbu, J.H., Bhurtel, B., Adhikari, A., Punam, G.C., Maharjan, M. \& Sunuwar, S. (2020). Fish community structure and environmental correlates in Nepal's Andhi Khola Province No. 4, Syangja. Borneo Journal of Resource Science and Technology, 10(2): 85-92. DOI: https://doi.org.10.33736/ bjrst.2510.2020

Limbu, J.H., Gurung, J., Subba, S., Tumbahangfe, J. \& Subba, B.R. (2021a). Correlation of fish assemblages with habitat and environmental variables in the Phewa Khola Stream of Mangsebung Rural Municipality, Ilam, Nepal. Journal of Animal Diversity, 3(2): 27-36. DOI: http://dx.doi.org/10.52547/JAD.2021.3.1.5

Limbu, J.H., Gurung, J.K., Subba, S., Khadka, N., Adhikari, A. \& Baniya, C.B. (2021b). An impact assessment of Betani irrigation dam on fish diversity of Damak Municipality, Jhapa, Nepal. Egyptian Journal of Aquatic Biology and Fisheries, 25(2): 163-175. DOI: 10.21608/EJABF.2021.161363

Mousavi-Sabet, H., Abdollahpour, S., Vatandoust, S., Faghani-Langroudi, H., SalehiFarsani, A., Salehi, M. \& Heidari, A. (2017). Reproductive biology of Alburnus mossulensis (Teleostei: Cyprinidae) in the Gamasiab River, western Iran. Iranian Journal of Ichthyology, 4(2): 171180. DOI: http://dx.doi.org/10.22034/ iji.v4i2.212

Moyle, P.B. \& Cech, J.J. (2000). Fishes: An introduction to Ichthyology: Fourth Edition, Prentice Hall. Upper Saddle River, New Jersey, USA.
Murua, H., Kraus, G., Saborido-Rey. F., Witthames, P.R., Thorsen, A. \& Junquera, S. (2003). Procedure to estimate fecundity of marine fish species in relation to their reproductive strategy. Journal of Northwest Atlantic Fishery Science, 33: 33-54. DOI: https://doi.org/ 10.2960/J.v33.a3

Mustafa, G., Islam, K.R., Ali, S. \& Alam, A.K.M.A. (1983). Some aspects of the biology of Puntius sarana (Ham.): Food and feeding habits in relation to fish size and fecundity. Bangladesh Journal of Zoology, 10(2): 92-100.

Nandikeswari, R., Sambasivam, M. \& Anandan, V. (2014). Estimation of fecundity and gonadosomatic index of Terapon jarbua from Pondicherry Coast, India. International Journal of Nutrition and Food Engineering, 8 (1):61-65.

Ng, H.H. (2010). Pseudecheneis sulcata. The IUCN Red List of Threatened Species 2010.

Prasad, A., Shrestha, A., Limbu, J.H. \& Swar, D. (2020). Spatial and temporal variation of fish assemblage structure in Seti Gandaki River, Tanahu, Nepal. Borneo Journal of Resources Science and Technology, 10(2): 93-104. DOI: https://doi.org/10.33736/bjrst.2048.2020

$\mathrm{R}$ Core Team. (2019). A language and environment for statistical computing. $\mathrm{R}$ Foundation for Statistical Computing, Vienna, Austria. URL https://www.Rproject.org/.

Rasheed, S. \& Mustaquim, J. (2010). Size at sexual maturity, breeding season and fecundity of three-spot swimming crab Portunus sanguinolentus (Herbst, 1783) (Decapoda, Brachyura, Portunidae) occurring in the coastal waters of Karachi, Pakistan. Fisheries Research, 103(1-3): 56-62. DOI: https://doi.org/10.1016/j.fishres.2010.02.002

Shrestha, J., Singh, D.M. \& Saund, T.B. (2009). Fish diversity of Tamor River and its major tributaries of Eastern Himalaya Region of Nepal. Nepal Journal of Science and Technology, 10: 219-223. DOI: https://doi.org/ 10.3126/njst.v10i0.2964

Shrestha, T.K. (2019). Ichthyology of Nepal. A Study of Fishes of the Himalayan Waters. 
Himalayan Ecosphere, Kathmandu, Nepal, Second edition, 2 pp and 19 pp.

Spjøtvoll, E. \& Stoline, M.R. (1973). An extension of the T-Method of multiple comparison to include the cases with unequal sample sizes. Journal of American Statistical Association, 68 (3): 975-978. DOI: https:// doi.org/ 10.1080/ 01621459.1973 .10481458
Thapliyal, A. \& Balodi, V.P. (2015). Statistical modelling of the fecundity of Pseudecheneis sulcata from river Alaknanda, Garhwal Himalaya. International Journal of Scientific Research, 4(5): 3-5. DOI: https:// www.doi.org/10.36106/ijsr 